\title{
ECD を用いた漏電および地絡表示器の開発
}

\author{
井上 浩* 二 宮 英 樹* \\ Leakage Current and Ground Fault Indicators Using ECD
}

Hiromu INOUE* and Hideki NiNOMIYA*

\begin{abstract}
Leakage current indicators using ECD (Electric Chromic Display) are developed. These indicators are characterized by the following points.

(1) Coloration density of the indicator shows electric charge which is integration of leakage current.

(2) The coloration density is held even if input current is stopped.

Fundamental characteristics of ECD are measured. Methods which hold coloring density, compensate coloring density depending on temperature and set the threshold of coloration are described. Leakage and ground fault indicators are fabricated. Minimum charges which display in leakage and ground fault indicators are $4.2 \pm 0.8 \mathrm{mC}, 4.9 \pm 1.1 \mathrm{C}$, respectively.

It was confirmed that the developed indicators were effective in electric power field.

Leakage current indicators help to determine the equipment in which insulation has broken down from lightning etc. and are useful in finding the equipment in which insulation is deteriorating.
\end{abstract}

Key Words : leakage current indicator, ground fault indicator, ECD

\section{1. はじめに}

電気事故の予防, 早期復旧の面から, 電力設備の絶縁 劣化の兆候や漏電した電力設備の早期発見を, 簡単に行 える方法が望まれている.

これまで,電力設備の絶縁劣化の兆候を発見するには, 接地線に記録計を取り付けて, 常時監視する方法1), 機器 の電位を測定する方法 ${ }^{21}$, 日常点検抢よび, 定期点検があ る. また漏電した電力設備の早期発見には, 事故発生後, 電流が流れた跡を目視によって発見する方法, メガ測定 や高電圧パルスにより絶縁抵抗を点検する方法がある.

しかしこれらの方法には多くの問題点がある。接地線 に記録計を取り付けて常時監視する方法および電位を測 定する方法は，多大の機材または人力を必要とし実用的 ではない.日常点検抢よび定期点検は，多大の人力と時 間を要し，より効率的な方法が望まれている。またこれ らの方法は，絶緑劣化の初期段階に発生する間欠的な地

$\dagger$ 電気学会全国大会で発表 $(1987 \cdot 4)$

* (株) 四国総合研究所電子技術研究所 松山市湊町 6-1-2

* Electrotechnical Lab., Shikoku Reserch Institute, Inc., Matsuyama

(Received June 10, 1991)

(Revised November 14, 1991)
絡電流を見落とすおそれがある。

つぎに漏電した電力設備を発見するため，電流が流れ た跡を目視により，発見する方法は，機器が焼損するな ど, 外観が変化した場合は有効であるが, 通常, 地絡継 電器 ${ }^{3)}$ が動作し, 短時間で地絡電流を遮断するため機器 の損傷まで至らない場合が多く, 常に有効とはいえない. メガ測定や高電圧パルスにより絶緑抵抗を点検する方法 は多大の時間と人力を必要とする. また最近の漏電事故 はシーケンサを内蔵した機器が複雑な動作をした結果, ある特殊な場合地絡事故を起こすことがあり, 早期発見 をさらに困難にしている4.

そこで筆者らは, 電流を積分した通電電荷量に比例し て着色濃度が増加し, 電流が遮断されても, その濃度が 保持される $\mathrm{ECD}^{5), 6)}$ (Electro Chromic Display) に着目 し, 小形で容易に取り付け可能な新しい漏電, 地絡表示 器を開発した7). これらの表示器は, 入力電荷量に比例し た着色濃度を得ることができる. しかも, 入力電流が途 中で途切れてもそれまでの着色濃度を保持するので, 間 欠的にあるいは, 短時間しか流れない地絡電流に対して 特に有効である. この漏電表示器は, 間欠電流が流れ発 見が難しい柱上がいしの絶縁不良を，早期に発見するた め開発された。また地絡表示器は, 電気故障が発生する 
と, 構内全体の停電となり故障場所の探索が著しく困難 となる変電所の地絡故障機器の発見を容易にするために 開発されたものである.

この論文は, 漏電および地絡表示器の具備すべき条件, これらの表示器の任様, ECD の基本的特性, 漏電および 地絡表示器の試作結果および利用方法について述べる.

\section{2. 漏電および地絡表示器の具備すべき条件}

漏電および地絡表示器は, 間欠的な地絡電流を検出・ 表示するため,電流の大きさとその継続時間を総合して, 検出する機能が必要となる。一方，現在の地絡故障に対 する保護方式では，零相電流の大きさと，その継続時間 の積の大きさにより地絡継電器が動作し, 電路を遮断す るようになっている。そこで, 漏電および地絡表示器の 検出は, 地絡継電器が動作する以前に検出できるように する.すなわち，これらの表示器の検出のための電荷量 (入力電流・継続時間) は, 地絡継電器の動作電流・時間 よりも小さい值とする。

漏電, 地絡表示器は, それぞれ電柱あるては, 変電機 器の接地線に取り付けるため, 屋外使用に耐える構造と する. また検出表示後; 外部から消色できる回路構成と

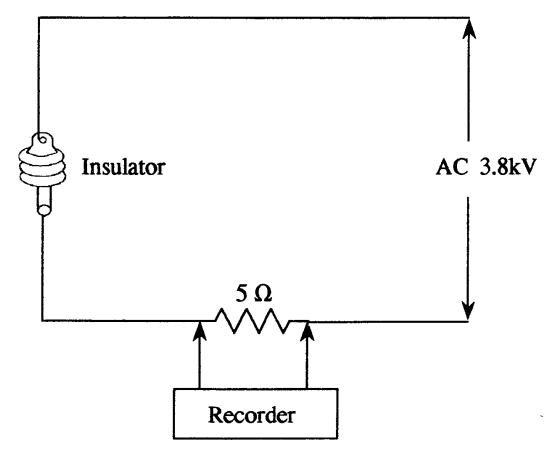

Fig. 1 Test circuit of insulator

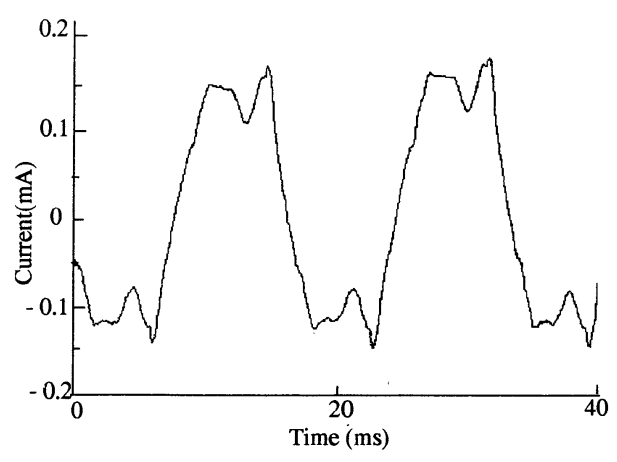

Fig. 2 Leakage current form of normal insulator
し繰り返し使用することとする.

つぎに, 漏電表示器の着色最小電流を検討するため, 高電圧がいしに流れる電流を測定した. Fig. 1 に測定回 路を示す. Fig. 2 に健全がいし $(1000 \mathrm{~V}$ メが, $2000 \mathrm{M} \Omega$ 以上)の電流波形を, Fig. 3 に不良がいし (1000 Vメガ, $1.2 \mathrm{M} \Omega$ )の電流波形を示す。これによると健全がいしの 漏れ電流は, ピーク值で $0.18 \mathrm{~mA}$ 程度のひずみ波であ る.これに対し不良がいしの電流はピーク值で $80 \mathrm{~mA}$ 程 度の正弦波に近い電流が流れていることがわかる。した がって $0.2 \mathrm{~mA}$ 程度の電流から着色し, それ以下では着 色しないようなしきい值を設定する必要がある.

また地絡表示器の着色最小電流を検討するため, 変電 機器の接地線に流れる電流を測定した. Fig. 4 は, 2 次変 電所内の $66 \mathrm{KV}$ 用, CT の接地線に流れる電流を測定し た一例である.これによると接地線にはピーク值で 0.45 $\mathrm{A}$ 程度の電流が流れている, 他の機器についても測定し たところ, 電磁誘導によって, 常時, 実効值で $0.1 \sim 0.4$ $\mathrm{A}$ 程度の電流が流れていることがわかった. したがっ て, $0.5 \mathrm{~A}$ 程度の電流から着色し, それ以下では着色しな いようなしきい值を設定する必要がある.

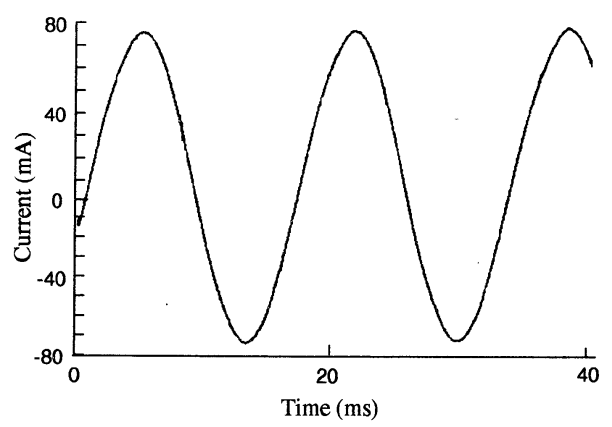

Fig. 3 Leakage current form of defective insulator

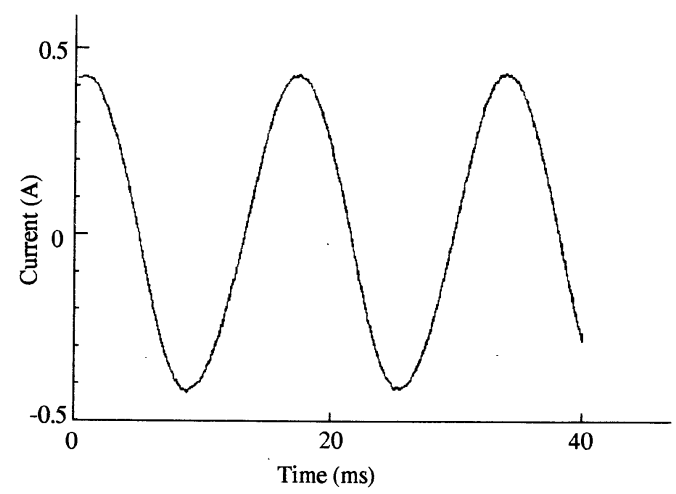

Fig. 4 Static induction current passed through grounding line 


\section{3. 漏電および地絡表示器の仕様}

試作した漏電表示器および地絡表示器の仕様を示す.

\section{1 漏電表示器}

前章で述べたように地絡電流は，がいしの絶縁程度に Terminal A より $0.2 \sim 80 \mathrm{~mA}$ の電流が流れる。また 6.1 節で述べる 地絡回線選択継電器の動作電流・時間は約 $1 \mathrm{C}$, 遮断する までの時間は約 $1 \mathrm{~s} に$ 設定されている。

そこで仕様としては $5 \mathrm{mC}$ 以上の電荷で, $0.5 \mathrm{~s}$ 以上継 続したと.き着色し， $0.2 \mathrm{~mA}$ よ小さい電流に対しては 着色しないようにした。

$\begin{array}{ll}\text { 着色最小電荷 } & : 5 \mathrm{mC} \\ \text { 着色最小時間 } & : 0.5 \mathrm{~s} \\ \text { 着色しきい值電流 } & : 0.2 \mathrm{~mA} \\ \text { 対象設備 } & : \text { 柱上がいし } \\ \text { 設備の電源電圧 } & : \text { 線間電流 } \mathrm{AC} 6.6 \mathrm{KV} \\ & \text { 対地電圧 } 3.8 \mathrm{KV}\end{array}$

\section{2 地絡表示器}

6.2 節で述べる 2 次変電所の地絡方向継電器の動作電

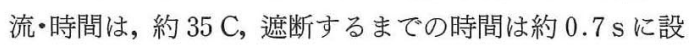
定されている。

そこで仕様としては $6 \mathrm{C}$ 以上の電荷で，電流が $0.1 \mathrm{~s}$ 以上継続したとき着色し， $0.5 \mathrm{~A}$ よりささい電流に対し ては着色しないようにした。

$$
\begin{array}{ll}
\text { 着色最小電荷 } & : 6 \mathrm{C} \\
\text { 着色最小時間 } & : 0.1 \mathrm{~s}
\end{array}
$$$$
\text { 着色しきい值電流：0.5 A }
$$$$
\text { 対象設備 : : 変電機器 }
$$$$
\text { 設備の電源電圧 ：線間電圧 AC } 66 \mathrm{KV}
$$$$
\text { 刘地電圧 } 38 \mathrm{KV}
$$

消色はどちらも外部端子を設け，巡視者が着色を確認 した後, 強制的に乾電池を使って着色と逆方向に電流を 流して消色する方法とした。また使用温度は $0 \sim 60^{\circ} \mathrm{C}$ と した。

以下，これらの表示器を試作するために，ECD の特性 を測定した結果を述べる。

\section{4. $\mathrm{ECD}$ の基本的特性}

\section{1 印刷型 ECD の構造と着色消色反応}

ECD は, 電気化学的可逆反応 (電解酸化還元反応) に よる物質の色変化現象を利用した表示素子である. ECD の材料には，酸化タングステンに代表される無機物質， ビオロゲン誘導体に代表される有機物質がある8 らについて比較実験をした結果，前者のほうが動作特性 や信頼性について優れているので，三酸化タングステン $\left(\mathrm{WO}_{3}\right)$ を用いた印刷型 $\mathrm{ECD}{ }^{9) \sim 11}$ を使用することとし

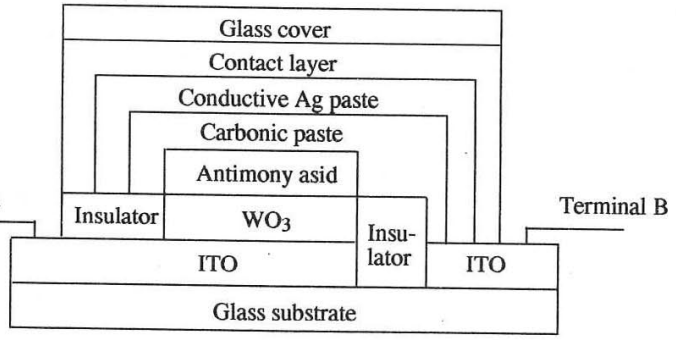

Fig. 5 Cross sectional view of ECD manufactured by screen printed method

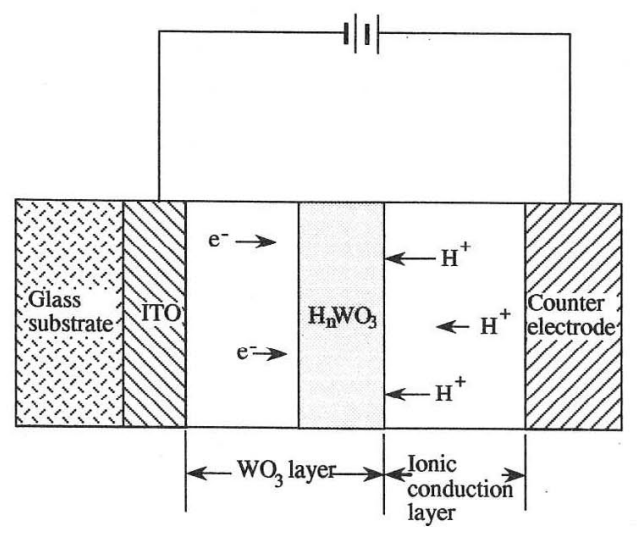

Fig. 6 Coloring process of ECD

た。

Fig. 5 に, 印刷型 $\mathrm{ECD}$ の原理的構造図を示す. $\mathrm{WO}_{3}$ 層 の片側にイオン伝導層である固体電解質層（アンチモン 酸)を介して，その両側に透明電極 (ITO) と対向電極(炎 素層）を配置した構造になっている。

$\mathrm{WO}_{3}$ 薄膜側を陰極とし, 対向電極側を陽極として電流 を注入すると，通電電荷量に比例したタングステンブロ ンズ $\left(\mathrm{H}_{\mathrm{n}} \mathrm{WO}_{3}\right)$ が $\mathrm{WO}_{3}$ 層に形成され，青色に着色する. この青色着色は, 逆電圧を印加することによって消色す $3^{6)}$. この電気化学反応式を(1)式に, Fig. 6 に, 着色時 の反応過程の模式図を示す。

$$
\mathrm{WO}_{3}(\text { 無色 })+x e^{-}+{ }_{n} \mathrm{H}^{+} \rightleftarrows \mathrm{H}_{n} \mathrm{WO}_{3}(\text { 青色 })
$$
ここで $e^{-}:$電子

$$
\begin{gathered}
\mathrm{H}^{+}: \text {プロトン } \\
n: \text { 個数 }
\end{gathered}
$$

\section{2 着色濃度の測定方法および濃度判定基準}

$\mathrm{ECD}$ の着色濃度を測定するため，レーザー光（波長 $0.633 \mu \mathrm{m})$ の入射光と反射光の強度で測定した．Fig. 7 に測定方法を示す。つぎの ( 2 )式で計算される $O D$ を, 光学的濃度とし, $\mathrm{ECD}$ の着色濃度 $\triangle O D$ をある基準の $O D$ の值からの差として定義した。 
4421992 年 4 月

$$
O D=l_{n}\left(r_{0} / r\right)
$$

計測自動制御学会論文集

ここで $O D:$ 光学的濃度

$$
r_{0} \text { : 入射光強度 }
$$

消色時の ECD は着色が少し残る場合があり, 着色濃 度の基準として $O D=0.1$ のときを $\triangle O D=0$ とした。着 色実験は，測定ごとに着色濃度をこの基準にもどして行 った。また目視による着色の判定基準として, 人が着色 したことを確認できる濃度を $\triangle O D=0.3$ とた。

Photo. 1 に着色例を示す.

\section{$4.3 \mathrm{ECD}$ の着色特性}

ECD に直流電圧を印加し印加電压に対する着色濃度 を測定した。測定方法は Fig. 7 と同じである。測定結果

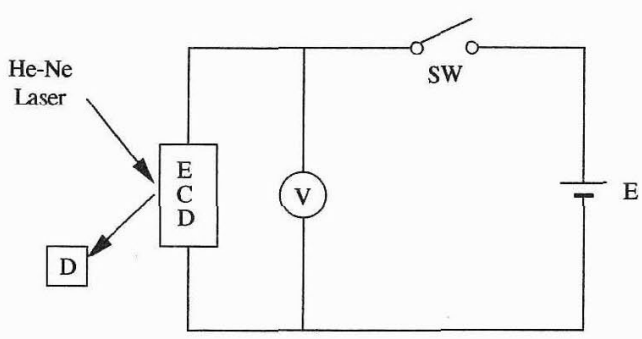

Fig. 7 Measuring set up of optical density D : Photo-detector,

ECD : Electro chromic display,

$\mathrm{V}$ : Voltmeter,

SW : Switch,

E : Constant voltage power supply
を Fig. 8 に示す。この図からは，電圧印加直後の着色濃 度は薄く徐々に濃くなっている。しかも印加電圧によっ て，着色濃度の飽和点が決まっている。このことは ECD を鮮明に表示するには，ある程度の印加電圧と印加時間 の両方が必要となる。

$\mathrm{ECD}$ の注入電荷量に対する着色濃度の温度依存性に ついて調べた。温度 $0 \sim 60^{\circ} \mathrm{C}$ 範囲で印加電圧と, 印加時 間を変化させ，流れた電流から計算した ECD の注入電 荷量と $\triangle O D$ との関係を Fig. 9 に示す。同図から $\triangle O D$ は流入される電荷量にほぼ比例して増加している。この 結果は，ECD が，入力電荷検出にうまく適合した表示素 子であることを示している。

ECDの着色保持特性について検討した。ECDに

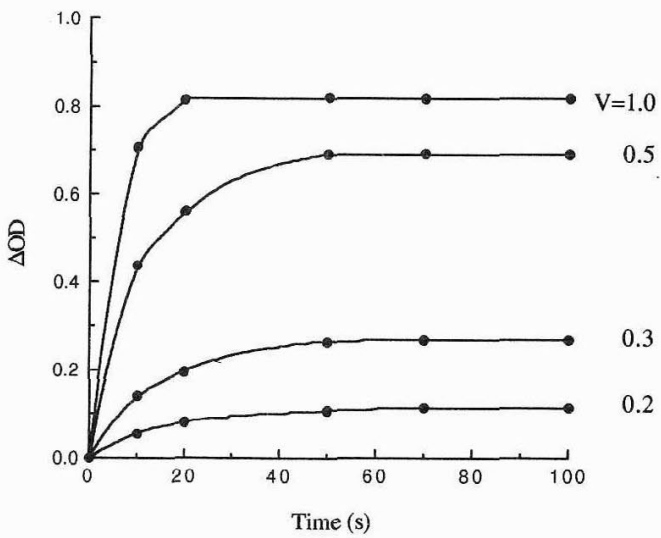

Fig. 8 Optical density vs. time characteristics

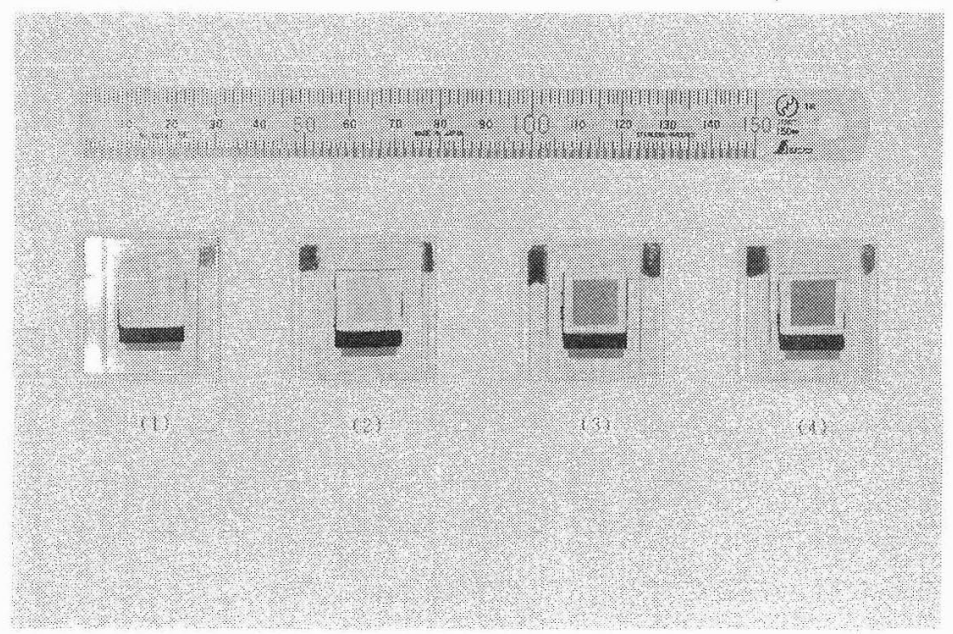

Photo. 1 Examples of cloration of ECD

(1) $\triangle O D=0.1$,

(2) $\quad 0.3$

(3) 0.5

(4) 0.8 
$2 \mathrm{mC} / \mathrm{cm}^{2}$ の電荷を注入後, 電極を開放した状態で, 着色 濃度 $\triangle O D$ と ECD 内部に蓄積された電荷によって発生 した電圧 $V_{e c d}$ の測定結果を Fig. 10 にす。また $2 \mathrm{mC} / \mathrm{cm}^{2}$ の電荷注入後, $\mathrm{ECD}$ の電極を短絡した着色濃度 の測定結果を Fig. 11 に示す. Fig. 10 では ECD が着色 しているときは, ECDの両電極間に電圧が発生してい

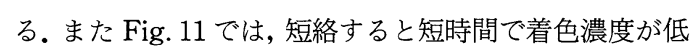
下していることがわかる. ECD の着色を長期にわたって 確保するには, ECD の電極を開放状態にしておく必要が ある.

つぎに, ECD の着色は電気化学反応であるため, 実際 の回路で, 着色濃度がどの程度温度により変化するかを 検討した. Fig. 12 に示すように, 分流抵抗 R を一定にし て端子 $\mathrm{A}, \mathrm{B}$ から $4 \mathrm{mC} / \mathrm{cm}^{2}$ の電荷を注入したときの $\mathrm{ECD}$ の温度と注入電荷量の関係を求めた. その結果を Fig. 13 の○印で示す. 同図では, 分流抵抗 R が一定のと き $\mathrm{ECD}$ の温度が変化すると注入電荷量が大きく変化し

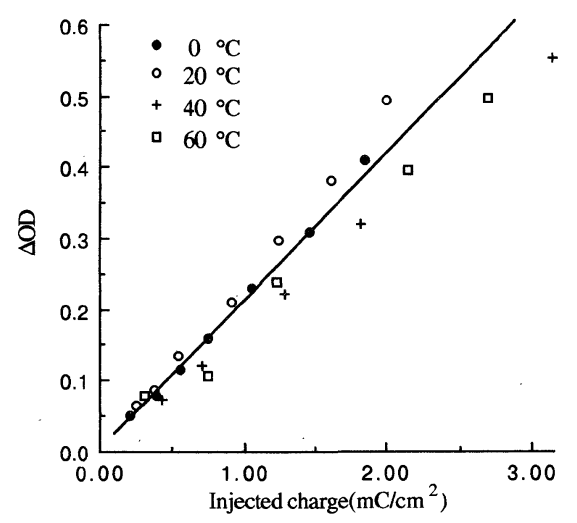

Fig. 9 Optical density vs. injected charge characteristic

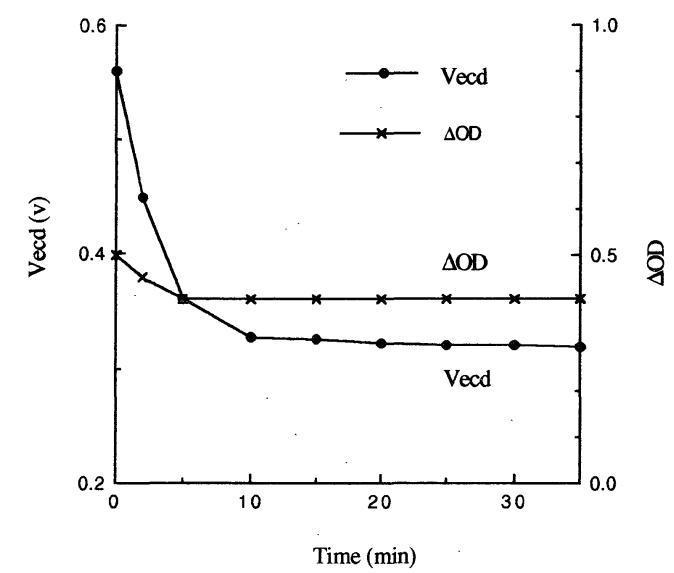

Fig. 10 Opened ECD voltage and optical density vs. time characteristics $\left(20^{\circ} \mathrm{C}\right)$
ている.これは, ECDの入力抵抗が温度により変化して いるものと考えられる. Fig. 14 に温度を変化させたとき の入力抵抗の測定值を○印で示す.

一方, $25 \sim 150^{\circ} \mathrm{C}$ におる $\mathrm{WO}_{3}$ 薄膜 $\mathrm{ECD}$ における直 流導電率 $\sigma$ は次式で示される ${ }^{12)}$.

$$
\sigma=\sigma_{0} \exp (-\varepsilon /(k T))
$$

ここで $\varepsilon:$ 活性化エネルギー

$$
k: \text { ボルツマン定数. }
$$$$
T: \text { 絶対温度 }
$$

したがって抵抗率を $\rho$ とすると，

$$
\rho=\rho_{0} \exp (\varepsilon /(k T))
$$

特に, 絶対温度 $T_{a}$ のとき, $\mathrm{ECD}$ の抵抗を $R_{a}$ とする と, 絶対温度 $T$ のときの $\mathrm{ECD}$ の抵抗 $R_{e}(T)$ は, $(4)$ 式 より次式となる.

$$
R_{e}(T)=R_{a} \exp \left\{B\left(1 / T-1 / T_{a}\right)\right\}
$$

(5) 式は温度 $T_{a}$ のとき, サーミス夕抵抗值を $R_{a}$, サー ミス夕定数を $B$ とするサーミス夕抵抗体の抵抗計算式 と同じ型になる13). またこの式は $1 / T$ を $X$ 軸に $l_{n}\left(R_{e}\right)$

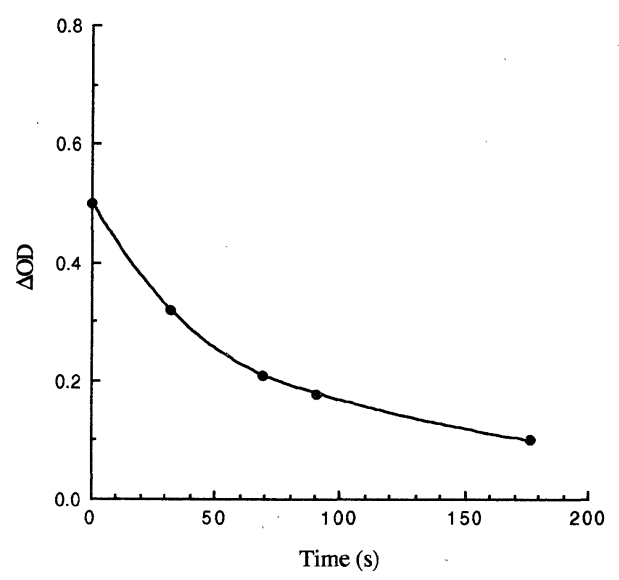

Fig. 11 Optical density vs. time characteristic of shorted $\operatorname{ECD}\left(20^{\circ} \mathrm{C}\right)$

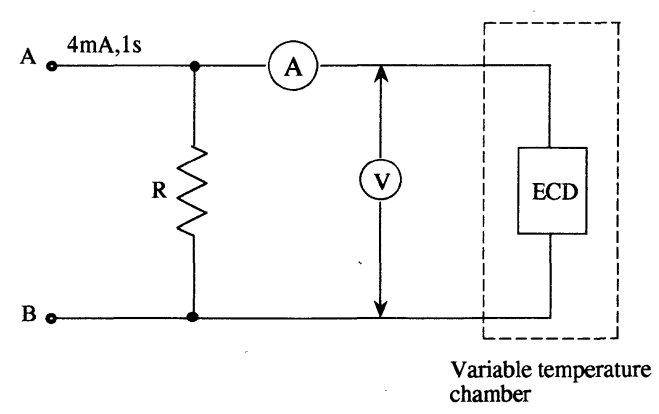

Fig. 12 Measuring set up of temperature dependence of coloration

$\mathrm{R}$ : Shunt resistance 
$\mathbf{4 4 4} 1992$ 年 4 月

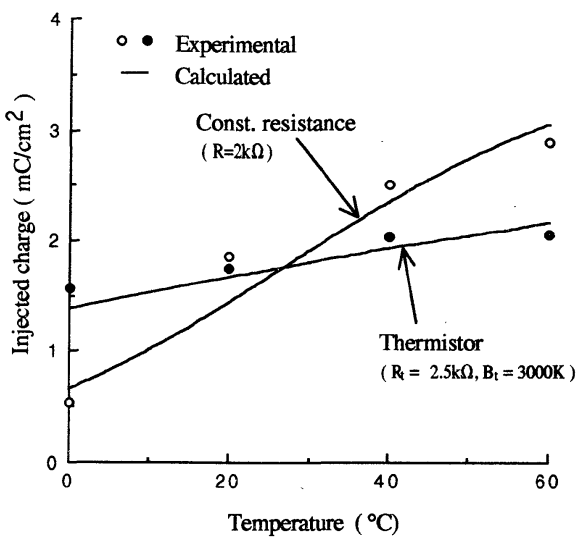

Fig. 13 Injected chàrge vs. temperature characteristics

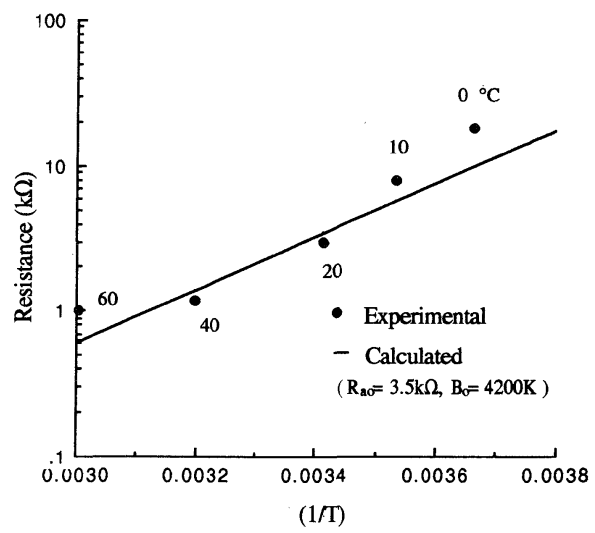

Fig. 14 Resistance vs. $1 / \mathrm{T}$ characteristic

を $Y$ 軸にした片対数グラフ上では傾きを $B$ とする直線 となるので, 測定值を近似する最適な直線を Fig. 14 に, その式を ( 6 ) に示す.このとき, 最適なサーミス夕定数 を $B_{0}$, 温度 $T_{a}$ のときの最適抵抗を $R_{a 0}$ とした.

$$
R_{e}(T)=R_{a 0} \exp \left\{B_{0}\left(1 / T-1 / T_{a}\right)\right\}
$$

Fig. 14 の場合の最適值は, $B_{0}=4200(\mathrm{~K}), T_{a}=293(\mathrm{~K})$, $R_{a 0}=3.5(\mathrm{k} \Omega)$ であった.

つぎに，Fig. 12 の分流抵抗 $\mathrm{R}$ をつぎの $(7)$ 式

$$
R_{t h}(T)=n /(1-n) \cdot R_{t} \exp \left\{B_{t}\left(1 / T-1 / T_{a}\right)\right\} \text { (7) }
$$

で示すようなサーミス夕抵抗体 $R_{t h}$ に変更し, $T=T_{a}$ のとき $R_{t}=R_{a 0}, B_{t}=B_{0}$ となるようなサーミス夕抵抗 体を選べば, 温度が変化しても端子 $\mathrm{A}$ から流入した電流 $I_{A}$ の $n(0<n<1)$ 倍が常に ECD に流れるようにするこ とができる，すなわち，ECD を流れる電流 $I_{e}$ は，

$$
I_{e}=R_{t h}(T) \cdot I_{A} /\left(R_{e}(T)+R_{t h}(T)\right)
$$

特に, $R_{t}=R_{a 0}, B_{t}=B_{0}$ のときは $(6),(7)$ 式を上式に代 入して,

$$
I_{e}=n I_{A}
$$

第 28 巻 第 4 号
(9)式では, ECD を流れる電流 $I_{e}$ は温度に無関係に端 子 $\mathrm{A}$ から流入する電流 $I_{A}$ の常に $n$ 倍となることを示し ている.

さらに, サーミス夕抵抗体を選ぶ場合 ECD の温度特 性を補償するのに最適なサーミス夕抵抗值 $n /(1$ -n) $\cdot R_{a 0}$, サーミス夕定数 $B_{0}$ が市販されているとはか ぎらないので，それらに近い值のものを使用する場合が ある、筆者らは漏電または, 地絡表示器をなるべく安価 に多数試作する必要があったので $R_{t}=2.5(\mathrm{k} \Omega)(n=0.5$, $\left.T_{a}=298(\mathrm{~K})\right), B_{t}=3000(\mathrm{~K})$ であるサーミス夕抵抗体 D 33 A を選んだ.

そこで Fig. 12 において R を抵抗にした場合と, サー ミスタにした場合とを比較した結果を Fig. 13 に示す. 実線は，（8)式を用いて ECDに流れる電流から電荷量 を計算した計算值である。このとき，抵抗 $\mathrm{R}$ は $2 \mathrm{k} \Omega$, サ ーミスタは上述の D $33 \mathrm{~A}$ を使用した。同図において 印は抵抗 R を使用したとき，○印はサーミスタを使用し たときの測定結果である。これによると，計算結果と測 定結果はほほ一致している。またサーミスタにしたほう が, 注入電荷量の温度変化が少ない. したがって, ECD の温度特性は ( 5 ) 式で示されるサーミス夕抵抗体の抵抗 計算式で記述でき，サーミスタを使って ECD の温度変 化による注入電荷量を補償することができる.さらに， ECD の着色は Fig. 9 から注入電荷量に比例しているの で, サーミスタにより ECDの着色温度補償ができるこ とがわかる。

\section{4 紫外線照射と着色}

$\mathrm{ECD}$ に紫外線を照射すると, $\mathrm{WO}_{3}$ 膜内に光電子が発 生し外部から電荷を与えたと同じように着色する ${ }^{12), 14)}$. このことは, ECD を屋外表示器として使用する場合に障 害となるため, 紫外線カットフィル夕を取り付ける必要 がある.Fig. 15 にキセンランプによる紫外線照射実験 方法を, Fig. 16 に実験に用いた紫外線カットフィル夕の 分光特性を示す.そしてキセノンランプの反射光のため レーザーを使った ECDの着色濃度測定が行えないた め, それにかえて紫外線照射時間と ECD 電極両端に誘

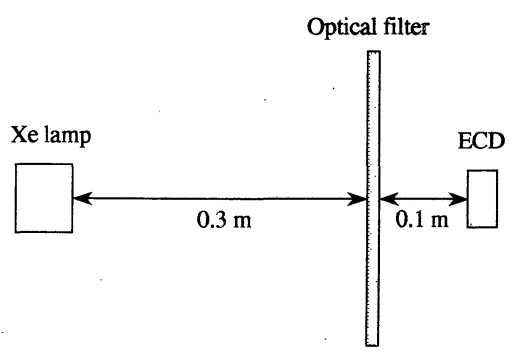

Fig. 15 Configuration of UV ray irradiation test 


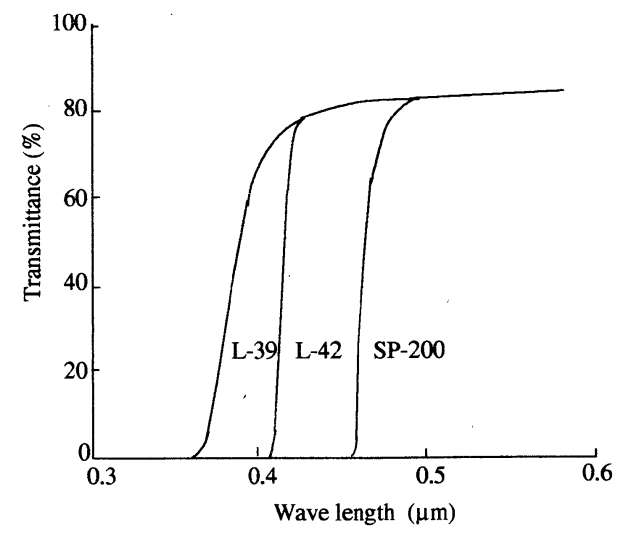

Fig. 16 Transmittance of optical filters

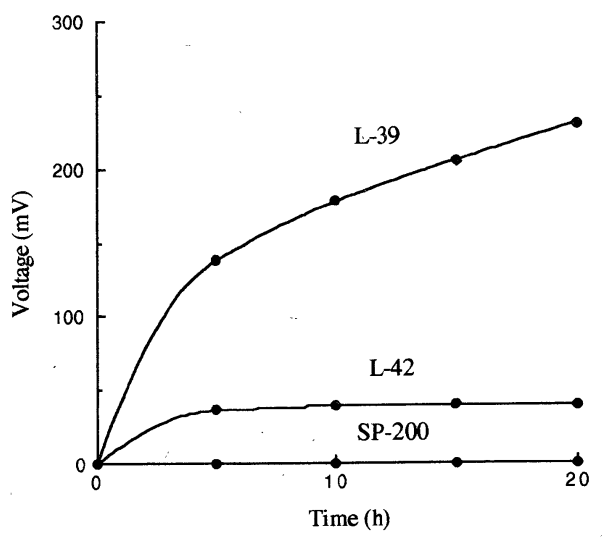

Fig. 17 Photo-induced voltages vs. time characteristic under Xe lamp

起された電圧を測定した. Fig. 17 にこの測定結果を示 す。ここで, L-39, L-42 はシャープカットガラスフィル タで, SP-200 は黄色透明のアクリル樹脂（厚さ $2 \mathrm{~mm}$ ) である. Fig. 17 に示すように, SP-200を用いた場合は着 色していない. L-39 と L-42 の場合は, 着色している.し たがって, 波長 $0.46 \mu \mathrm{m}$ 以下の短波長を遮光することに より ECDの紫外線による着色は防止できる。また SP200 で ECD 表面を覆い, 太陽光の当る屋外で暴露試験を 2 年間行った結果着色は認められなかった。

\section{5 着色開始電圧の設定}

着色のためのしきい值を設定する場合, 定電圧ダイオ 一ドを利用したしきい值回路が考えられるが，一般的に

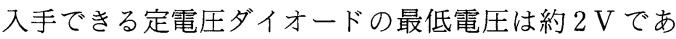
り, 本研究では高感度の漏電, 地絡表示器を開発してお けば，感度を低下させることは容易であることから，さ らに低い設定值を得ることができるダイオードの順方向 電圧特性を利用することとした. Fig. 18 は, ECD に直列

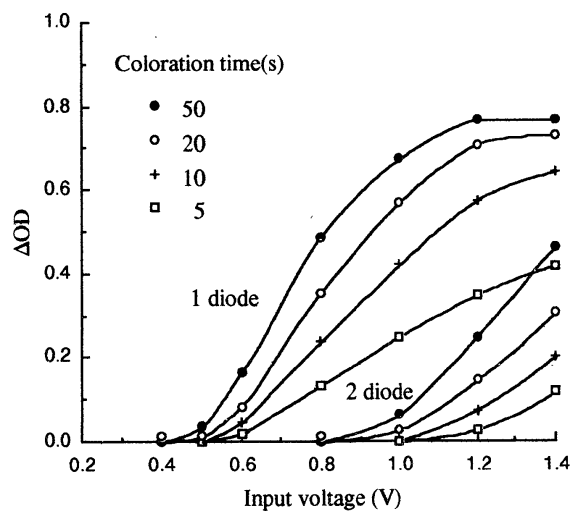

Fig. 18 Optical density vs. input voltage characteristics

にダイオードを接続したときの印加電圧と着色濃度の関 係を示している.ダイオード 1 本のときは $0.4 \mathrm{~V}$, ダイオ ード 2 本のときは $0.8 \mathrm{~V}$ からそれぞれ着色し始めてい る.このようにダイオードの直列接続の個数で, 着色の しきい值電圧を増減させることができる。

\section{5. 漏電および地絡表示器の試作}

\section{1 回路ブロック}

$\mathrm{ECD}$ の基本的測定結果をもとに設計された漏電およ び地絡表示器の基本的な回路ブロックを Fig. 19 に示 す. 端子 A, B に交流電圧を印加する. 基本的な回路ブ ロックは, 分流器または変流器, 整流回路, ダイオード を用いたしきい值回路, 温度補償用のサーミスタ $\mathrm{Th}$, ECD の発生電圧を保持するダイオード Dr から成り立っ ている.

電気設備の絶縁が劣化し, 接地線を流れる電流が増加 すると, 入力回路の出力端子 $\mathrm{C}, \mathrm{D}$ の電圧が上昇する. そ してしきい值回路の設定值を超え, ECD に電流が流れ着 色する，もし，地絡継電器が動作して電路を遮断するか

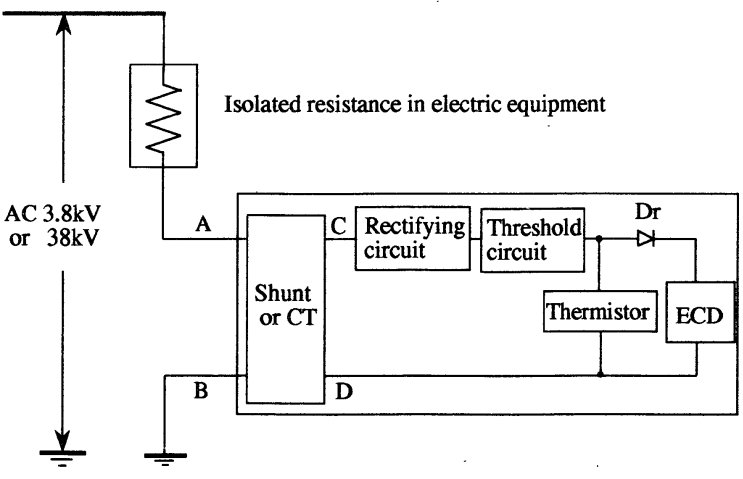

Fig. 19 Block diagram of leakage of ground fault indicator 
4461992 年 4 月

あるいは, 電気設備の絶縁が回復して漏れ電流が流れな

くなった場合，ECD に発生した電圧は Drによって保持 され，着色が長期間保存される。

\section{2 漏電表示器の回路および感度特性}

試作した漏電表示器の回路を Fig. 20 に示す. 端子 A, Bから注入された電流は, 整流用ダイオードによりサー ミスタと ECDに分流されている. 整流回路は, ブリッジ 整流を採用し, 着色しきい值電圧はブリッジ整流回路の ダイオードの順方向電圧を利用した. サーミスタは ECD の着色濃度が温度により変化するのを補償するためのも

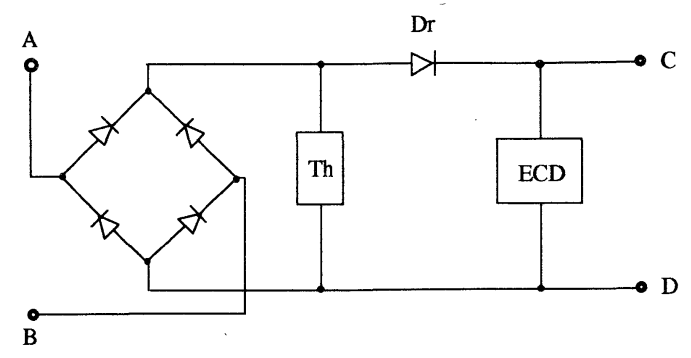

Fig. 20 Circuit of leakage indicator

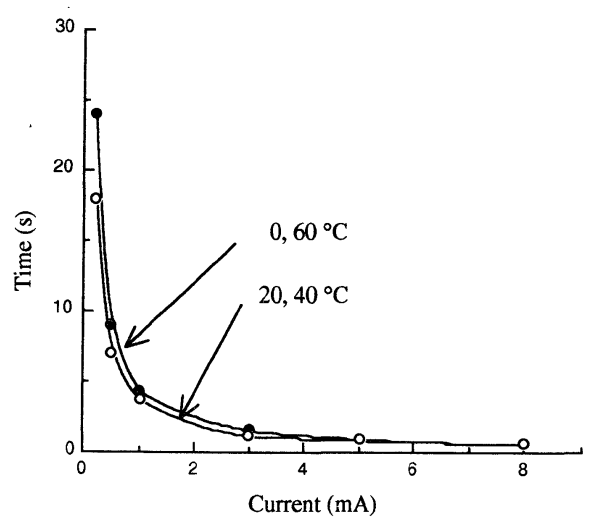

Fig. 21 Time vs. current characteristics of leakage indicator at $\triangle O D=0.3$
第 28 巻 第 4 号

のであり，4.3 節で述べた D $33 \mathrm{~A}$ を用いた。端子 C，D は, $\mathrm{ECD}$ を着色したときと逆方向の電圧を外部から印加 して消色する端子である.この回路で使用したダイオー ド Dr は一般整流用ダイオード $1 \mathrm{D} 4$ である.

Fig. 21 に $\triangle O D=0.3$ を着色表示させるため, 端子 A, $\mathrm{B}$ から注入された電流と,その継続時間との関係を示す. 実験の結果，しきい值電流は $0.2 \mathrm{~mA}$, 着色最小時間は $0.5 \mathrm{~s}$ であった. Fig. 22 は, 温度と注入電荷量との関係を 示している. 同図から, 温度範囲 0 $60^{\circ} \mathrm{C} て ゙, 4.2 \pm 0.8$ $\mathrm{mC}$ の入力電荷で着色判定基準 $\triangle O D=0.3$ を得ること ができた. Fig. 23 に外観図を示す.この漏電表示器は小 形軽量であり電柱の接地線に簡単に取り付けることがで きる。

\section{3 地絡表示器の回路および感度特性}

Fig. 24 に試作した地絡表示器の回路を示す. 地絡電流 の入力には接地線に取り付けが容易な分割型変流器を使 つている. 整流回路には平滑用コンデンサC が追加され ている. その他は, 漏電表示器の回路と同じである.コ ンデンサC の值は, 瞬時的な入力電流に対しても着色す

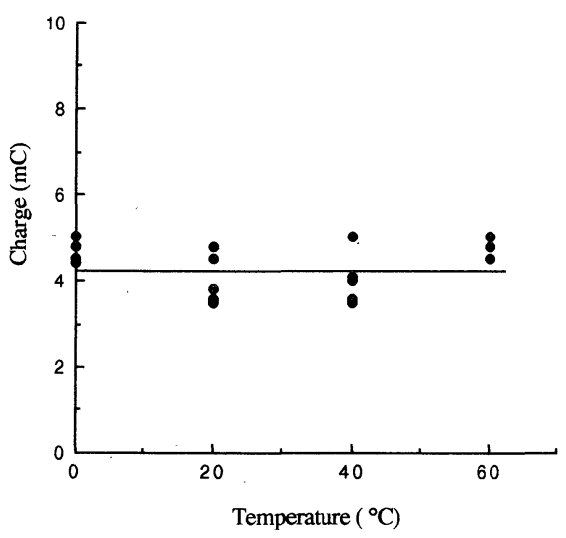

Fig. 22 Injected charge of leakage indicator to obtain $\triangle O D=0.3$

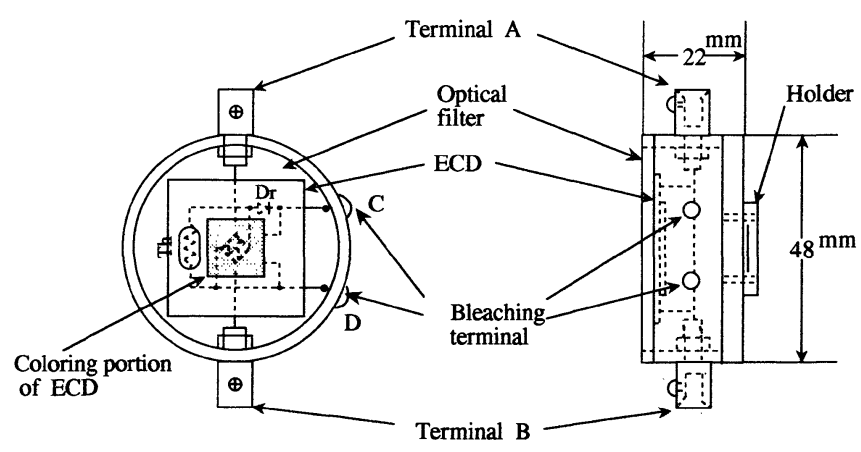

Fig. 23 Leakage indicator 


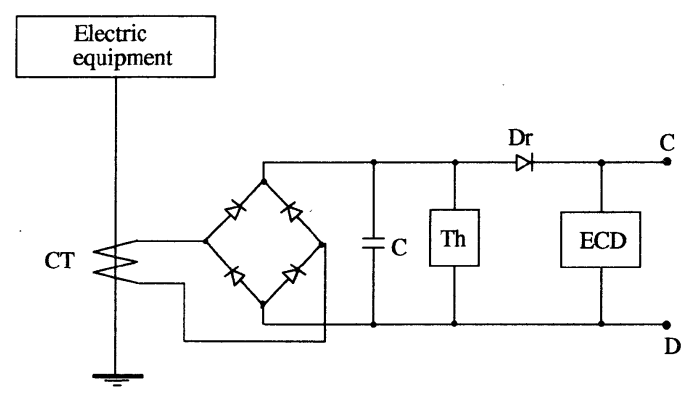

Fig. 24 Circuit of ground fault indicator

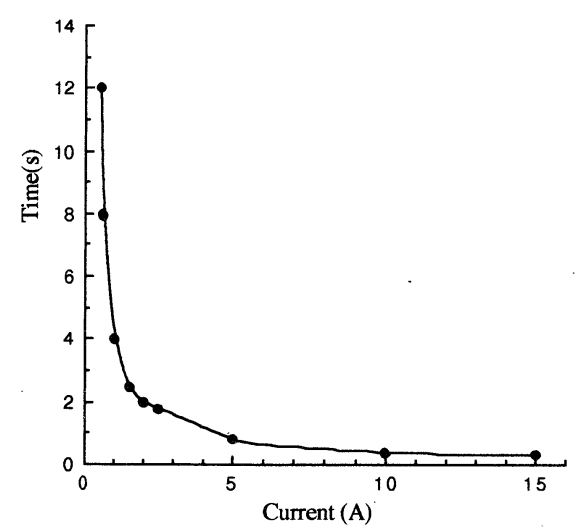

Fig. 25 Time vs. current characteristic of ground fault indicator at $\triangle O D=0.3$

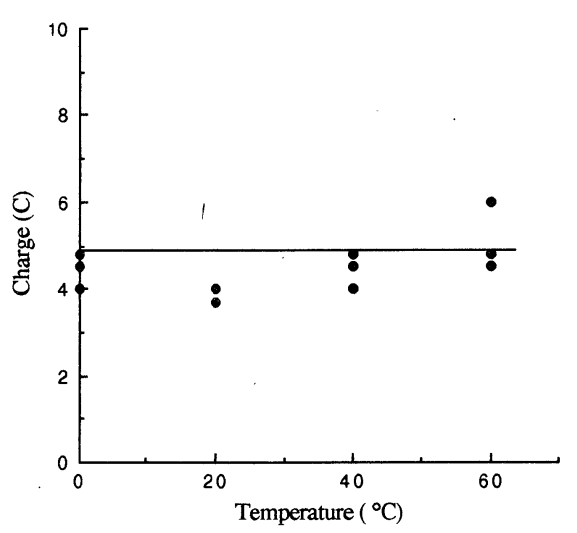

Fig. 26 Injected charge of ground fault indicator to obtain $\triangle O D=0.3$

る最適容量を実験的に求めた。その結果は $33 \mu \mathrm{F}$ であっ た。

Fig. 25 に $\triangle O D=0.3$ を着色表示するため, 変流器の 1 次側に流れる電流とその継続時間との関係を示す。実 験の結果, しきい值電流は $0.5 \mathrm{~A}$, 着色最小時間は $0.1 \mathrm{~s}$ であった. Fig. 26 は, 温度と流入電荷量との関係を示し ている. 同図から $0 \sim 60^{\circ} \mathrm{C}$ 範囲で $4.9 \pm 1.1 \mathrm{C}$ の入力電

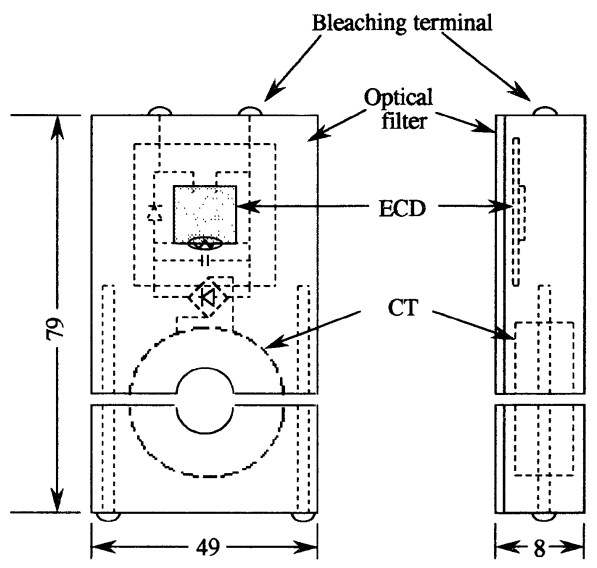

Fig. 27 Ground fault indicator

荷で $\triangle O D=0.3$ を得ることができた。

Fig. 27 に外観図を示す. この地絡表示器は, 小形軽量 であり, 変電機器の接地線に簡単に取り付けることがで きる。

\section{6. 漏電および地絡表示器の利用方法}

\section{1 漏電表示器}

配電線地絡保護のため, 地絡回線選択継電器が設置さ れている。電柱上でのがいしの絶縁が低下すると, 接地 線に漏れ電流が流れ, この地絡回線選択継電器が零相電 流を検出する．この電流の大きさがある時間継続して設 定值を超えると, 地絡回線選択継電器が動作し, その配 電線を停電させる. 配電系統の設置方式がリアクトル接 地方式の場合は, $1 \mathrm{~A}$ の零相電流が $1 \mathrm{~s}$ 程度継続したと き, すなわち $1 \mathrm{C}$ 程度の電荷で地絡回線選択継電器は電 路を遮断する. この漏電表示器は, それよりも小さい 5 $\mathrm{mC}$ で検出することができる，そこでこの漏電表示器を Fig. 28 に示すように, 電柱の接地線に取り付けておけ ば, 地絡回線選択継電器が電路の遮断を開始する以前に 着色するので, その濃度を確認することにより, 電柱単 位で絶縁劣化したがいしを発見することができる。この 表示器は地絡回線選択継電器が動作するよりも, 非常に 小さな電荷で動作するので, 地絡回線選択継電器が電路 を遮断する以前に漏電を検知できる. そこで, あらかじ め多くの電柱の接地線にこの表示器を取り付けておき, 巡視点検時に着色濃度が濃くなったところから, 順番に 漏電個所の改善を行うこともできる。

\section{2 地絡表示器}

変電設備の地絡保護のため, 地絡方向継電器が設置さ れている.この地絡方向継電器の設定は 2 次変電所での 構内事故の場合約 $0.7 \mathrm{~s}$ であり, 1 線地絡事故の場合, 接 


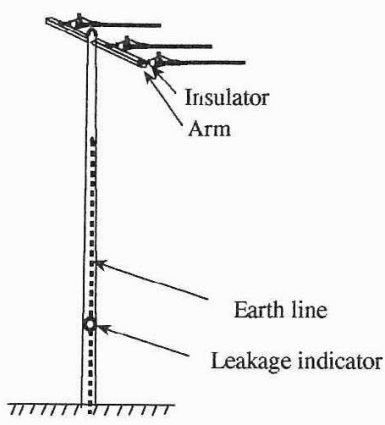

Electric pole

Fig. 28 Installation of leakage indicator on electric pole

地線に $50 \mathrm{~A}$ 以上の地絡電流が流れる。一方, 落雷などに より瞬時的に地絡電流が流れた場合は，この地絡方向継 電器で検出できる時間より地絡時間が短いため, 停電に はならない。しかし何回も落雷を受け，電気絶縁が低下 してくると地絡方向継電器は地絡電流を検出し, 停電を 引き起こす。この停電は, 変電所全体の停電となり, 故 障場所の発見が著しく困難となる。地絡事故は気象条件 の悪いときに発生する頻度が高く，地絡場所を発見する には多大の人力と経験を要する。そこで，あらかじめ機 器の接地線にこの地絡表示器を取り付けておけば, 地絡 方向継電器が動作する以前に地絡電流が流れた跡を容易 に発見することができる。

\section{7.おわりに}

ECD の着色特性を利用した小形の漏電および地絡表 示器の開発を行った。

本稿で述べた表示器は，零相電流により電路を遮断す る地絡継電器などとは異なり, 漏電電荷量を着色濃度で 表示するものである。

$\mathrm{ECD}$ の基本的特性を測定し着色保持, 温度補償, 着色 のためのしきい値回路および紫外線による誤着色防止フ イルタについてテストした結果, 実用的な漏電および地 絡表示器を試作することができた。漏電表示器は微小漏 れ検出用に, 地絡表示器は, 比較的大きい地絡電流の検 出用に使用される。

これらの表示器は, 地絡故障時の不良機器の探索だけ でなく, 故障を起こす以前の予防段階での絶縁劣化機器 の早期発見に有力な手段となることを 2 例について述べ t.

これらの表示器の精度をさらに上げるためには，ECD そのものの着色メカニズムを検討する必要があり, ECD の電気的等価回路の考察などが今後の研究課題となる。
最後にECD の提供を受けた凸版印刷(株)および貴重 なご指導を賜った岡山大学の中田高義教授に心から感謝 いたします。

\section{参 考 文 献}

1) 小松 嚴：変電所の機器異常監視システムの開発動向,電 気現場技術，9 (1988)

2) 徳本, 三好：漏電電纴測定による不良碍子の発見方法, 電 気現場技術，11，43/45（1986）

3) 電気学会編：電気工学ハンドブック,946,電気学会 $(1978)$

4）本田稔基：やっかいもの間欠漏電, 電気と工事, 29-9, 29/ 36 (1988)

5) C. J. Schoot, J. J. Ponjee, H. T. van Dam, R. A. van Doorn and P. T. Bolwijn : New Electrochromic Memory Display, Applied Physics Letters, 23-2-15, July, 64/65 (1973)

6）浜田 浩：ディスプレイ・ディバイスの可能性 $\mathrm{ECD}$ (エレ クトロクロミック)，電子技術，24-10，57/60（1982）

7) 二宮, 井上, 水渓, 松平 : ECD 利用の漏電-地絡検出器, 電気学会全国大会, 1503 (1987)

8）矢口正親：新しい多色パネルーエレクトロクロミックディ スプレイ, 電子通信学会誌, 67-7, 807/816 (1979)

9）二宮,ほか：ECDを用いた漏電表示器, 第 5 回エレクトロ クロミー研究会資料，Feb., 1/3 (1987)

10）松平, 吉田, 二宫：表示素子の新しい流れ-ECD を中心と して, 第 14 回境界領域における電気化学セミナ, Aug., 1/ 7 (1986)

11）松平，吉田：印刷方式に上る固体エレクトロクロミック・ ディスプレイ，電子技術，26-2，59/63 (1984)

12) S.K. Deb: Optical and Photoelectric Properties and Colour Centres in Thin Films of Tungsten Oxide, Phil., Mag., 27 (1973)

13）電気学会編：電気工学ハンドブック，230/231, 電気学会 (1978)

14) R. V. Pole, G. T. Sincerbox and M.D. Shattuck: Photoinduced Electrochromic Effect and Its Applications to Displays, Applied Physics Letters, 28-9-1, May, 494/497 (1976)

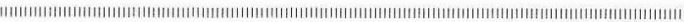

\section{[著 者 紹 介]}

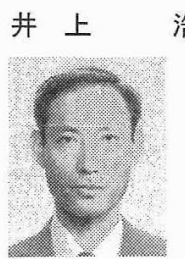

浩（正会員）

1972 年, 大阪大学大学院工学研究科修士 課程修了. 同年四国電力 (株) 入社. 1987 年, (株)四国総合研究所，現在に至る。主に電 力分野での設備骖断，ロボット化技術の研 究に従事. 電気学会, 電子情報通信学会な どの会員.

\section{二 宮 英 樹}

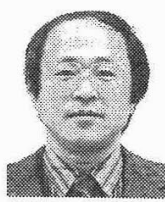

1981 年, 甲南大学大学院自然科学研究科 博士課程修了. 1982 年, 四国電力 (株) 入社. 1987 年, (株) 四国総合研究所, 現在に至る. ガスレーザー，金属蒸気レーザー，レーザ 一計測の研究に従事. 理学博士.レーザー 学会, 応用物理学会の会員。 